\title{
The Apostle Peter communicating his divinely inspired message to the Jews
}

\author{
Dr. Mike Megrove Reddy \\ Department of Communication \\ University of Zululand, South Africa \\ E-mail: ReddyMM@unizulu.ac.za \\ DOI: https://doi.org/10.46222/pharosjot.102.032
}

\begin{abstract}
This article sought to answer the question 'what are the communication forms employed by Peter the Apostle to the Jews?. The aim article seeks to highlight the communication forms employed by the Apostle Peter and to describe the various forms of communication used by him The theoretical framework used in the paper was the Shannon and Weaver Communication Model. A desktop research methodology was employed and information was gathered from journal articles, books, and internet sources. Due to this being a historical type of research, much of the literature was gathered from theological sources. The paper argues that Christian communication should be recognised within the field of communications, as Christian organisations used various forms of communication to maintain and propagate teachings and beliefs that are still valid today.
\end{abstract}

Keywords: Christianity, communication, types of communication, divine communication, Apostle Peter.

\section{Introduction}

God first communicated with man in the Garden of Eden when he communicated with Adam and Eve. However, it was man's disobedience that made God to evict Adam and Eve from the Garden. God still spoke through His servants and prophets, etc. God spoke to Abraham and told him to take his son Isaac to the region of Moriah and sacrifice him there as a burnt offering (Genesis 22). God spoke to Moses in the burning bush (Exodus). These are examples of God speaking to man. Even though man had sinned, God had already prepared a way of atonement for man's sins through the death of Christ with Christ being the ultimate sacrifice for human sin. In the New Testament era, Peter was an important communicator of God's message for salvation. He was a man with name change signifying his speficic and important role. The Bible records other instances of individuals whose names have been changed and Peter would have known of such (Abram to Abraham and Jacob to Israel). So, likewise in the case of Peter from a disciple of the Lord, to an Apostle, to the key person who would be used in establishing the church. The arrival of Christ on the scene turned many lives around to the extent that they left their earthly professions to follow a man who preached about God's love for all humankind, irrespective of their background. For example, Matthew was a tax collector, Peter a fisherman, etc. However, on meeting Christ, His twelve disciples gave up their professions and followed Him.

The Apostle Peter was called to take the gospel to the Jews race. However, there were instances in the New Testament which show he also preached to the Gentiles. The apostle Peter used various forms of communication which were available to him during his time so that he could maintain and propagate the gospel of Christ. The two key types of communication are between man and God and between people. As people communicate with God, the first thing is to listen. God's key ways of communication with people is through His Word (Romans 10:17) and after the resurrection of Jesus through the Holy Spirit (John 14:26). However, people such as the Apostles also played a key role in communicating the Word of God. 
However we are exhorted to be honourable in our communications, for example in Proverbs 12:22 (ESV) we read: "Lying lips are an abomination to the Lord, but those who act faithfully are his delight'. Also we need to show understanding as it is stated in Proverbs 17:27 (ESV) "Whoever restrains his words has knowledge, and he who has a cool spirit is a man of understanding". Jesus also tells us that our words are critically important: "For by your words you will be justified, and by your words you will be condemned." (Matthew 12:37) (ESV)

After the ascension of Christ, Peter became the most influential disciple of the twelve Christ had chosen. He preached the first message on the day of Pentecost and used various forms of communication and also wrote two epistles. Peter was regarded as the 'rock' on which Christ had built the church (Nicolaides, 2010). All of the disciples of the Lord were Jews and therefore Peter began his ministry by focusing on preaching to the Jews and they were his main target audience. The apostle Peter's original name was Simeon or Simon. He was a fisherman of Jewish origin and the son of Jonah or John. He came from a place called Bethsaida (John 1: 44) and lived in Capernaum (Mark 1:29). He came to know the Lord Jesus through Andrew his brother who was a disciple of John the Baptist. Andrew heard John the Baptist declaring that "Jesus was the Lamb of God" (John 1: 35-36). The name Peter occurs 162 times in the New Testament (Abarim Publications; 2021). He was a fisherman by trade. He was one of twelve disciples of Jesus Christ, one of the most important early pillars of the Christian faith. He was among the three who were in the inner circle of Jesus.

The Etymology of the name Peter shows it is derived from the Greek word "pétros" which means 'stone, rock.' In Biblical Greek, it is written as Пєтро५. He was commonly referred to or was known as Peter, Simon, and Cephas (White, 2021). The name Simon Peter Eínwv Пદ́тро appears in total nineteen times in the New Testament. In Aramaic the new name Christ gave Simon was Cephas (Aramaic) or Peter (Greek) which means 'rock' (Got Questions, 2021). The Apostle Peter was first presented in the New Testament as Simon ( $\Sigma i \mu \omega v$ in Greek). His name is also spelled twice in the New Testament as Simeon ( $u$ uncẃv in Greek). However, his encounter with Christ brought about a name change to Cephas from Aramic כִיפָא (Kephra), whose literal meaning is 'stone' or 'rock' (Wilson, 1979; Siecienski, 2017). In the writings of the Apostle Paul, he is referred to as Peter or Cephas in the Letter to the Galatians and the Letter to the Corinthians. The Apostle Paul refers to him and the other two apostles who were James and John as the pillars of the church (Galatians 2:9). "Peter was enthusiastic, strong-willed, impulsive, and, at times, brash. But for all his strengths, Peter had several failings in his life. Still, the Lord who chose him continued to mold him into exactly who He intended Peter to be" (Got Questions, 2019, n.p.). Jesus Christ states in Matthew 16-18: "And I also say to you that you are Peter, and on this rock, I will build my church, and the gates of Hades shall not prevail against it." His brother Andrew was also a disciple of Christ. At the death of Christ, Peter as well as the other disciples were disillusioned and went back to their previous way of life. Peter returned to the fishing trade to sustain himself and his family. Initially, Peter had his shortcomings in his walk with Christ. However, after the day of Pentecost, he rose to leadership instantly and became the most influential amongst the twelve apostles.

The Apostle Paul stated that the Apostle Peter took his wife with him on his missionary trips (1 Corinthians 9: 5). The other apostles also took their wives with them on missionary trips. His mother-in-law was healed by Jesus and this is recorded in three of the four gospels (Matthew 8: 14-17, Mark 1: 29-31, Luke 4: 38-39). From this, we can see that Peter was a married man. Reddy (2018: 7) states "Mark tells us of Jesus' reproach of Peter (8: 32-33), and also demonstrates the extent of Peter's failure and disavowal of Christ (14: 27-31, 66-72)". Abarim Publications (2021: n.p.) states: John adds the detail that Andrew was initially a disciple of John the Baptist, who heard Jesus speak (together with an unnamed colleague) and switched masters. Right after that he went to his brother Simon and recruited him too. On this occasion, Jesus renamed him Cephas, which is a Syriac name and 'which is translated Peter' (John 1: 35-42). John also adds the detail that Peter and Andrew were from Bethsaida in Galilee (John $1: 44)$. 
The two letters which are accepted to be writings of his were written before his death. They are 1 and 2 Peter. He is regarded as the first bishop or pope by the Catholic church and is regarded as the first patriarch of Antioch by the Eastern Christian traditions. He is regarded as the apostle used by the Lord to establish the Church of Antioch. Pope Clement of Rome (96 CE) stated that the Apostle Peter was martyred during the reign of Emperor Nero. The origin of the writings of Eusebius (232 CE) stated Peter was crucified head down. However, Christ prophesied that Peter would die a martyr's death (John 21: 18-19).

\section{Communicating the Word}

The Apostle Peter played a vital role in maintaining and propagating the gospel through the use of various forms of communication. The communication forms he used needed to be interpersonal and also a group type of communication which would allow for a greater understanding of issues, conveying information and influencing decisions made by believers and non-believers. In fact "Communication involves much more than just what we do as humans. Communication is the breath (pneuma or spirit) of our common existence. The world is dependent on and affected by inter-relationship (communication) between all things - even animals and what we have thought to be inanimate objects" (Horsfield, 1996).

Forms of communication used will vary based on the context and settings. Throughout history, we have seen the evolution of writing taking place. Throughout history, we have seen how new forms of communication were developed and made communication much easier even though it would be expensive initially. Interpersonal communication, intrapersonal, upward, downward, horizontal, verbal, small group, divine, supernatural, public, and written communication were the various types of communication that were greatly used in church during the first-century.

The Bible is the written document of God's self communication to humanity. It testifies that it is the word of God irrespective of one's weltanschauung and culture and thus invariably influences and shapes human opinions (Nicolaides, 2020). In the book of Exodus, God commits the dialogue to write on two tablets of stone we call the Ten Commandments. (Exodus 3,6) and the word of God is God's words and not man's in any sense (2 Peter 1:1921).

It would have been great if Peter wrote a gospel based on him spending time with the Lord Jesus Christ. Because there would be a lot of things he would have encountered with Christ which would have been a great blessing to the body of Christ. Jesus knew how to communicate and get through people's psychological barriers and Peter clearly learned much from Jesus who knew how to proceed from an individual's need to tough spiritual truths. Jesus knew that by targeting His message to receptive people, His truth would multiply through disciples fashioned after His image. "Jesus knew how to present truth in a holistic way that showed effective use of non-verbal and verbal forms of communication. Our Lord was a genius at using facial gestures to his audience to accent oral communication. By using His entire lifestyle as the embodiment of truth, Jesus communicated by example" (Fritz, 2000).

There is a gospel of Peter, however, it was rejected as Apocryphal by the Catholic Church synods of Rome and Carthage, when they established the New Testament, The very incarnation of Jesus the Logos, is a divine communication happening which occurred in a worldly environment. The Incarnation is then in essence an expression of God's selfcommunication to humanity (Nicolaides, 2019). Christ functioned in His divine nature, and also in His human nature and used communication to inform people of His Kingdom, both individually and communally. Christ satisfied our need for greater understanding in both individual and communal settings.

The advancement of Christianity was possible because the Roman Empire had modernised life and trade when they came into power. Reddy (2004: 75) states "although the forms of the old republic were preserved, the Senate was subservient and the real power was in the hands of 
Augustus, the sole ruler of the Roman Empire in $27 \mathrm{BC}$. Then after years of ruinous civil war, the Empire brought permanent peace. The Pax Romana, (the Roman Peace), embracing the civilized world, was the prime requirement for the healthy development of commerce and general well-being." Reddy (2002: 75) further states that "a great improvement in the administration of the provisional governments kept governors in check and as opposed to previously, had the good of the whole empire in view instead of a mass of wealth for individuals. There was order instead of chaos and despite oppression and injustice the reign of Roman law, in relation to ancient standards, was a beneficial thing."Over time, there was vigorous progress of commerce through the rule of Augustus. Reddy (2002:75) posits that "safe and easy communication was on the cards not just for commerce, civil and military administration, but also for Christianity. The development of roads rendered land travel easier than before. Brigands on land and pirates at sea were in check; as a result, travel became a common thing. However, there remained perils of rivers, perils of robbers, perils in the wilderness, etc. as recorded in 2 Corinthians, 11:26. Missionary life remained difficult but not impossible." One won't be able to fathom how difficult missionary work would have been had all these advancements not been implemented by the Roman empire.

\section{Theoretical Framework}

Figure 1. Shannon and Weaver Model of Communication

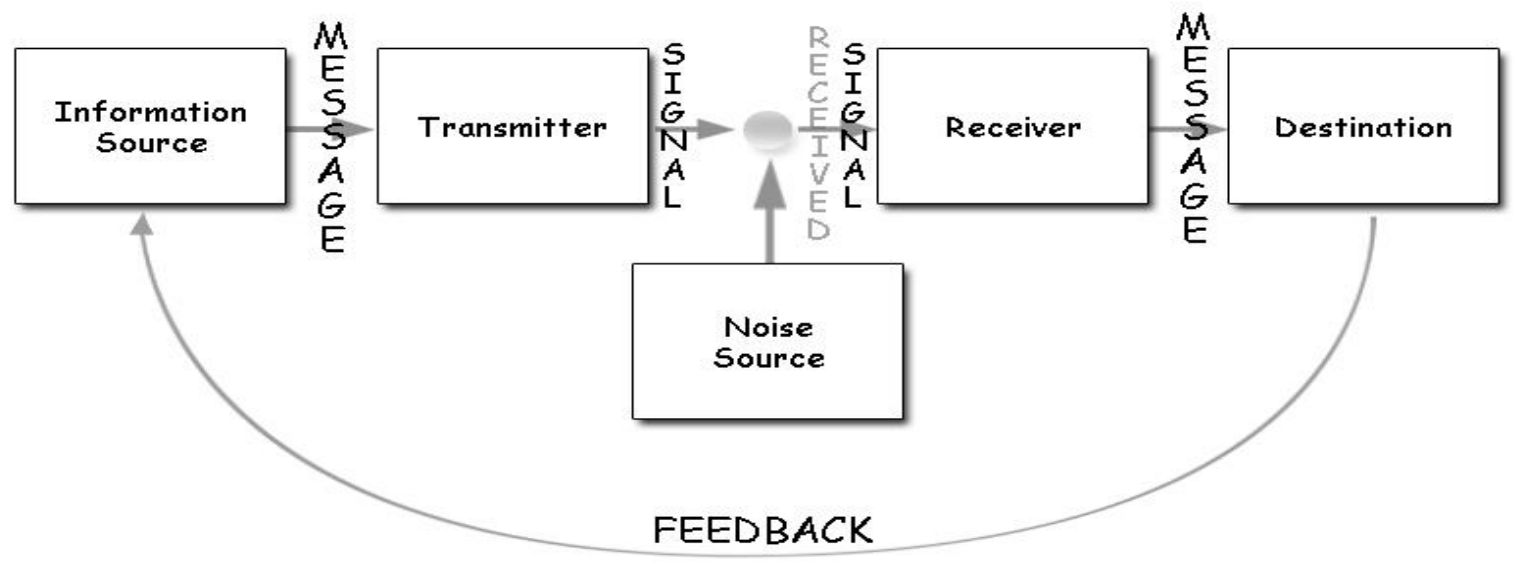

Source: Mishra (2019: np) Shannon and Weaver Model of Communication

The Theoretical Framework used in this paper is the above Shannon and Weaver Model of Communication. In this model of communication, we have the sender, message, medium, receiver, feedback, and barrier (Shannon \& Weaver, 1949). The role of the sender is to send the message to the receiver through a medium. The sender first encodes a message before he/she sends it. The message is what is sent or communicated by the sender. The medium is the method used in sending the message. The receiver is the individual who decodes the message (Mishra, 2017). Barriers are regarded as hindrances that cause stumbling blocks when receiving the message. Feedback is when the sender can conclude whether the receiver decoded the correct message sent. The sender, when applied in the context of this paper, will be the Apostle Peter. He used verbal, interpersonal, small group, and public, divine communication, downward communication, upward, and lateral and was also engaged in confrontational communication (Galatians 2:11), and finally, written communication. The receiver will be his audience, which at times was those who heard him as he preached the word of God. The apostle Peter's major barrier was that he never wrote many epistles and he only wrote epistles to the Jews and never wrote any epistles to the Gentiles as such. So the first leader of the church excluded the Gentile audience from his writings.

Another barrier could have been the nonverbal communication and when the one hundred and twenty believers were gathered in the upper room when the Holy Spirit ascended on them, 
those that noticed them thought they were drunk. Had it not been for the Holy Spirit on the day of Pentecost, Peter's major barrier would have been for the different tribes to hear the message in their language. In today's context, a major barrier can be whether Christians are receptive or not to who the sender of the message is and if they would accept it or not. Like in the day of Pentecost the people accused the 120 of being drunk.

\section{Forms of communication employed by Peter for the maintenance and propagation of the gospel}

The word communicate is a word that comes from the Latin word communicare, which means to make common or share (The New Book of Knowledge, 1976: 429). Communication is when an individual can send a thought or an idea to another individual that attaches a certain meaning to thought, therefore enabling communication to take place (Forest \& Olson, 1981:7). According to Reddy (2002: 12) "the ability to communicate effectively provides an advantage in reaching personal and occupational goals. It should be noted that through communication we establish, develop and maintain relationships, and through communication we form and terminate relationships." Peter's whole ministry spells out that he used communication to its fullest.

During the first encounter with the Lord Jesus Christ, it was clear he maximized the various forms of communication at His disposal. Written communication is the only form of communication Christ had not used during His earthly ministry. Peter would have observed from Christ and would have learned how to engage with small and large crowds. On the day of Pentecost Peter preached to a very large crowd as did Christ during His earthly ministry. Peter had the same experience on the day of Pentecost as he preached to a large crowd. Under the guidance and power of the Holy Spirit, he preached and each person was able to hear him in their language, a miracle in itself. The gospel of Mark shows the influence of the Apostle Peter's preaching and eyewitness memories.

Verbal Communication is spoken words. "Speech communication generally emphasizes verbal aspects of transmitting message" (Reddy, 2002: 28). Verbal communication includes all communication using spoken words, or even unspoken words as in sign language. It is important to understand how one should effectively communicate ideas verbally so as to circumvent misunderstandings and take full advantage of interest while speaking. An example will be Peter communicating on his different trips as recorded in the book of Acts, which he undertook with the Apostle John. Verbal communication is evident throughout the life of the Apostle Peter as he communicated with Christ, other apostles, and the other believers and even with nonbelievers and even when he had to appear before the Sanhedrin. But one noticeable communication of note is his interaction with John Mark (1 Peter 5: 13). John Mark wrote the first gospel which contains the life of Christ. It was based on Peter's remembrances of his time with Christ. According to the Book of Acts, there were four sermons by Peter which are mentioned (Acts 2: 14-41, 3: 12-26, 10: 34-43, 15: 7-11). These are referred to as public oral communication. He started using public oral communication, after Pentecost as a major form of communication to propagate their beliefs of the gospel of Jesus Christ.

There was also confrontational communication which became evident between Peter and Paul. During the time Peter was eating with the Gentiles and when the Jews came, he left to go and sit with the Jews. Paul rebuked him in the presence of everyone because of what he had done. Luke writes in the Acts of the Apostles, put simply the works of the Apostle, which does not only cover the works of the Apostle Paul but all the others too. Twice, he, together with John, was brought before the Sanhedrin and he defiled them (Acts 4: 7-22, Acts 5: 18-42). He preached with boldness before the Sanhedrin (Acts 4).

According to Acts 8: 14, Apostle Peter and the other apostles were sent from Jerusalem to Samaria. It was only after his vision which he had from God, accordingtowhich he was allowed 
to eat unclean animals that he undertook missionary journeys to Lydda, Joppa, and Caesarea (Acts 9: 32 - Acts 10: 2). According to Acts 10, it is clear that he also did evangelism to the Gentiles. For the Apostle Peter the understanding of the vision of eating the unclean animals referred to Gentiles. Here we see his ability to interpret a vision enabled him to take the gospel to the Gentiles also. Whilst in prison the Apostle Peter is awakened by an angel of God. The angel verbally communicates with the Apostle Peter, and he listens to the instruction of the angel and leaves (Acts 12). "Then, he was present when the Samaritans received the Holy Spirit (Acts 8). Finally, he was summoned to the home of the Roman centurion Cornelius, who also believed and received the Holy Spirit (Acts 10). In this way, Peter 'unlocked' three different worlds and opened the door of the Church to Jews, Samaritans, and Gentiles" (Got Questions, 2021).

"Grapevine is also known as word of mouth communication. Information that is communicated 'through the grapevine' can be verified (Reddy, 2002:18). This is evident throughout the life of the Apostle Peter before the Gospel of Christ or the teachings of the church were documented. Hearsay is something which is not regarded as factual. According to the Oxford Advanced Dictionary of Current English, the definition of hearsay is as follows, it is "common talk; rumour; what one has heard another person or other person say: I don't believe it; it's merely hearsay. Hearsay evidence is not accepted in law courts." The Jews did not want to believe that Jesus was the Messiah because they were expecting someone to deliver them from the Romans. "Interpersonal communication is communication which takes place between individuals. Interpersonal communication is most often face-to-face communication" (Reddy, 2018:18). An example of this is when Peter communicated with Jesus. Or when he communicated with his fellow Apostles. Intrapersonal communication is communication that takes place within oneself.

Diverse cultural contexts undoubtedly brought new communication challenges to Peter. "Intercultural communication is communication among people of different cultures" (Reddy, 2002: 18). Tubbs and Moss (1978: 8) quote Samovar and Porter "whenever the parties to a communication act bring with them different experiential backgrounds that reflect a longstanding deposit of group experience, knowledge, and values, we have intercultural communication." This was evident, as it can be witnessed on the day of Pentecost as people from different tribes heard Peter preach his first sermon.

Nonverbal communication is when one communicates without any form of speech or written documents. It "takes place through means other than the use of words, such as facial expression, gestures, body language, touching, spacing, systematic use of time, posture or general body movements" (Reddy, 2018: 28). Forrest and Olson (1981: 102) posit "Nonverbal messages are particularly appropriate for sharing emotions, feelings, and attitudes." Luke 22: 54-62 is an ideal example of nonverbal communication, when Peter denied the Lord the third time and he wept bitterly. Reddy (2002: 23) states that written communication "Requires greater facility with words and language than does verbal communication". A message is often expressed in writing because a spoken message is impossible. Peter wrote two epistles, which are mentioned also in this paper, entitled First and Second Peter.

"Organisational communication is all forms of communication that take place among members of organisations, either big or small. It is therefore sometimes also referred to as internal communication" Reddy (2018: 23). Initially, the early believers were called the people of The Way, but at the Council of Jerusalem, they were called Christians. This showed that they had moved from a movement phase into becoming an organisation and Jesus' brother James was elected as its head. The first major issue that was discussed was the issue of circumcision and whether Gentiles could enter the church.

"Public communication occurs where a speaker does most of the talking and the audience does most of the listening" (Mersham and Skinner, 1999: 173). This took place on the day of Pentecost. Small group communication is when small groups of people gather together to 
achieve a common goal or purpose. This took place when believers gathered together to have fellowship and they went from house to house. Lateral communication "is communication between individuals of equal status; worker-to-worker, manager-to-manager" (Reddy, 2002: 28). This is also known as horizontal communication. Upward communication is when a junior communicates with a senior person. This is also known as vertical communication. An example is communication from believers to the apostles and from the other apostles to Peter as Peter was seen as the head of the early church. "Downward communication is when the superior disseminates information to their subordinate" (Reddy, 2002: 28). An example is Peter communicating to those below him and teaching them about how they should do ministry. Divine Communication or supernatural communication is when humans communicate with a supernatural being or when a supernatural being (God or angels) communicates with humans, through prayer, prophecy, visions, dreams, and the Word (Bible), or worship. "God communicates to man through revelation. According to his will and purpose, he communicates directly to individuals, or through the scriptures, or through prophets and others He has chosen" (Shuster, 2013).

The Apostle Peter had a vision of killing and eating unclean animals (Acts 10: 9-23). From this, we see he encountered divine communication. Supernatural Communication is the working of the Spirit of God within a man or woman or divine being to bring about the manifestation of miraculous workings of God, which goes against natural laws and principles. Peter was used by God to heal a man at the temple. See the scripture below (Acts 3:1-9). "One day Peter and John were going up to the temple at the time of prayer-at three in the afternoon. ${ }^{2}$ Now a man who was lame from birth was being carried to the temple gate called Beautiful, where he was put every day to beg from those going into the temple courts. ${ }^{3}$ When he saw Peter and John about to enter, he asked them for money. ${ }^{4}$ Peter looked straight at him, as did John. Then Peter said, 'Look at us!' ${ }^{5}$ So the man gave them his attention, expecting to get something from them. ${ }^{6}$ Then Peter said, 'Silver or gold I do not have, but what I do have I give you. In the name of Jesus Christ of Nazareth, walk.' 7 Taking him by the right hand, he helped him up, and instantly the man's feet and ankles became strong. ${ }^{8} \mathrm{He}$ jumped to his feet and began to walk. Then he went with them into the temple courts, walking and jumping, and praising God. ${ }^{9}$ When all the people saw him walking and praising God,"

When the Apostle Peter was in prison the angel appeared before him and removed the chains and told him to put on his clothes and leave the prison (Acts 12: 7-10). There was also another supernatural encounter mentioned in Acts 16: 26 where the ground shook and everyone's chains fell of, "Suddenly there was such a violent earthquake that the foundations of the prison were shaken. At once all the prison doors flew open, and everyone's chains came loose" (Acts 16: 26). An appropriate example of Supernatural communication is recorded in Acts 5: 15, "As a result, people brought the sick into the streets and laid them on beds and mats so that at least Peter's shadow might fall on some of them as he passed by."

\section{The writings of the Apostle Peter}

There have been two letters that have been ascribed to Peter the apostle of the Lord. They are called 1 and 2 Peter. In the following description, I shall give a brief description of these two letters.

\section{The First Epistle of Peter}

According to John 1: 40, Peter is referred to as a humble fisherman. Therefore, it could be wise to assume that he was one of limited learning and understanding. Reddy (2002: 90) states that "even under the direct tutelage one sees on a number of occasions what Christ meant by these things spoken. Peter is the only apostle of whom this theme of self-limiting belief runs through, not just in the gospels but also in the book of Acts." Peter was introduced to the Lord by his brother Andrew (Matthew 5: 8) who was also a disciple of the Lord and who was first a disciple 
of John the Baptist. The many interactions Christ had with Peter were to develop him for a more prominent role of leadership which would take place in the future. In looking at the life of Peter we see two things, firstly the growth in understanding and secondly the growth in spirituality (Bockmuehl, 2010; Meyendorff, 1963). Even though Peter denied the Lord three times on the night of the Lord Crucifixion, he did repent and made a turnaround in his life (1 Peter 5: 1). According to Luke, the medical doctor, it was Peter who stood in front of the crowds on the Day of Pentecost to address them. If I would entitle the message I would call it "You Crucified the Son of God, however, God raised Him from the Dead." Peter also became the chief witness in regards to the early Christian Church (Acts $2-12$ ).

The Apostle Peter identifies himself as the writer of the Gospel (1 Peter 1: 1 ). The writer is well known for the suffering endured by Christ during his ministry (1 Peter 5: 1). As part of external evidence as to who wrote this epistle, it is ascribed to the apostle Peter by the early church fathers. There were two target audiences he generally had in mind in this epistle. One was the Christians in Asia and the other those who were scattered abroadd. These Christians he referred to as pilgrims and strangers. He referred to them as strangers and pilgrims. As stated early in this paper, he was crucified head down. The reason was that he felt he was not worthy enough to die like his master. From reading this epistle one can conclude that it was written for maintenance and propagation purposes.

\section{The Second Epistle of Peter}

According to 2 Peter, the author identifies himself as Simon Peter, the servant of the Lord. Here we see he exhorts Christians to diligently pursue godliness and to have genuine knowledge of Christ. Through his writings, he also exposes the false teachers and false prophets who were among the churches within Asia Minor, who were guilty of creating dispute when it came to the teachings of the apostle. Like his previous epistle, this epistle is also written for maintenance and propagation.

According to Vander Heeren, (1911) if we consider works external to the New Testament, a number of apocryphal books were ascribed to him, especially the Acts of Peter, Gospel of Peter, Preachings of Peter, Apocalypse of Peter, and Judgment of Peter, although scholars believe these works to be pseudepigrapha.

In summing up, the Apostle Peter used various forms of communication. From verbal communication, nonverbal communication, interpersonal communication upward communication, downward communication, lateral communication, small group communication, organisational communication, public communication grapevine and written communication tothe divine communication.

\section{Ministry of Peter to the Jews}

The Apostle Paul states in Galatians 2: 8 (NIV) "For God, who was at work in Peter as an apostle to the circumcised, was also at work in me as an apostle to the Gentiles." The NLT is more specific, "For the same God who worked through Peter as the apostle to the Jews also worked through me as the apostle to the Gentiles." This shows that the Apostle Peter's main target audience was Jews. However, there would be many times he would have address non-Jews, like on the Day of Pentecost. The same applies to Mary Magdalene who had to contend with diverse groups of believers (Nicolaides, 2018).

If we interrogate scriptures suc as Acts 1:8, Matthew 28:19, Matthew 28:19-20, we ascertain that Jesus gauged the type of communication to each audience and spoke pure truth creatively. His communication kept the audience engrossed. He spoke with authority and this surely rubbed off on Peter. In fact the Apostle Peter emulated Jesus style at times and communicated through 
questions and preaching. Sound dialogue built communication and relationships in which there was feedback and clarification. Peter, like Jesus, communicated so that people would be transformed in their thinking by life changing decisions (Fritz, 2000).

Peter states in Peter 1: 1-2 "1Peter, an apostle of Jesus Christ, God's elect, exiles scattered throughout the provinces of Pontus, Galatia, Cappadocia, Asia and Bithynia, ${ }^{2}$ who have been chosen according to the foreknowledge of God the Father, through the sanctifying work of the Spirit, to be obedient to Jesus Christ and sprinkled with his blood: Grace and peace be yours in abundance." From this introduction, it is clear that the Apostle Peter's target audience was Jews, but those who were dispersed. Demars (2019: np) posits "At first blush, the wording suggests that Peter is addressing ethnically Jewish followers of Jesus. He calls them the 'chosen' - Israel was God's chosen nation in the Old Testament. He refers to them as 'exiles' - the Jewish people had been exiled from their homeland by the Babylonians in 586 B.C.E."

Though some may debate the target audience by stating that it was also meant for gentiles, this is mistaken, as Demars (2019: n.d.) quotes the words of John Calvin which are as follows regarding the audience in his commentary of 1 Peter: "They who think that all the godly are thus called, because they are strangers in the world, and are advancing towards the celestial country, are much mistaken, and this mistake is evident from the word dispersion which immediately follows; for this can apply only to the Jews." Nicolaides $(2010 ; 2021)$ states that there was need to grow the Church of the Lord, and so it was clearly necessary to communicate with new adherents on a large scale at times and to provde a eucahristic feast for them. In the time of Jesus it was rather challenging to communitae a message with others. Commiunication was not integrated and extensive in various ways such as economically, socially and of course technologically. Nonetheless the quality of communication needed to be very personal and also communal in orientation.

Demars (2019: n.d.) highlights four reasons why he believes the intended audience was Jewish followers of Jesus. They are as follows:

1. A straightforward reading of $1: 1$ supports a Jewish audience. Diasporas refer to Jews in the biblical text (John 7:35, James 1: 1).

2. Peter's critique of their former way of life actually applies quite well to Hellenistic Jews in the Roman Empire.

3. Peter's use of Old Testament prophetic imagery points to a Jewish audience.

Peter explicitly distinguishes his readers from "the Gentiles" (2: 12; 4: 3-4). Peter's speeches were very general, in essence he enhanced the whole New Testament preaching of salvation through only Jesus. "Peter is the first great witness. He lays the foundation on which Christ builds His Church. But together with his name the names of all the other apostles will be written upon the twelve foundations of the new Jerusalem (Revelation 21: 14; cf. Ephesians 2: 20)" (Ridderbos, 1961).

\section{Conclusion}

The word of the Lord came to pass in the life of the Apostle Peter. Truly he was a 'fisher of men'. He became the 'rock' that the Lord would use to work and through which the church would be built. Even though he was called to share the gospel to the Jews, on the day of Pentecost, though he was addressing or preaching focusing on the Jews, some people who belonged to different tribes listened to him. Here were see public communication. The book of Acts shows he did missionary trips to other places. It shows he went to Cornelius's home. Here we see interpersonal communication. He used the various forms of communication at his disposal during his day to maintain and propagate the gospel so that many would come to know the saving grace of Jesus Christ. He used interpersonal communication, downward and upward and later small group communication (when they went from house to house), pubic 
speaking (day of Pentecost), written communication (the two epistles 1 and 2 Peter), divine communication / supernatural communication. Peter was much like the Apostle Paul wrote in Romans (14:19), "So then we pursue the things which make for peace and the building up of one another". He offered those he heard his messages immense hope, to all the persecuted Christians in a world of Roman paganism, and guided them with practical instruction through effective sincere communication.

From the above paper, it is clear that the Apostle Peter was called by Christ to be a preacher to the Jews even though the Apostle Paul was more learned in the scriptures. Peter was a disciple or mathetes, which means a learner, and was willing to gain needed skills and knowledge, and greater wisdom and understanding so he could be an effective communicator of the Holy Gospel. The epistles in the New Testament underpin the stories related in the Gospels and the Apostle Peter used the accounts of the Scriptures when he communicated in the synagogues throughout the Roman Empire.

Peter was often headstrong and spoke before thinking (Mark 8:32-33, Mark 9:5). At times he told Jesus what to do and said foolish things. He was also a very outspoken person and was likely to get very over-enthusiastic. This shows us God's willingness to use anyone willing to be used for His glory by communicating with others. Even though he was called to be an apostle to the Jews, scriptures show that Peter also took the gospel to the Gentiles and continued with an active ministry to and was the revered leader of the Jewish segment of the Church while Paul was working mainly with Gentiles (Galatians 2:8). Peter followed Jesus and communicated His Truth in both word and deed. "Peter holds up the goal of becoming godlike in every sense of the term" (Anderson, 1991). Peter was super diligent, hardworking, and industrious and communicated well despite his shortcomings. His life provides communication lessons that we ought to seek to apply in our daily communication with others. He eagerly encouraged his readers to live holy lives emulating Jesus: "Be holy yourselves in every aspect of your conduct" (1 Peter 1:159). Peter's communication always maintained and promoted the unity, holiness, universality and the notion of the apostolicity of the Church while asserting that it is Jesus who is the source of all good things.

\section{Dedication}

This paper is dedicated to two influential individuals. Firstly, Prof Vijay Rugbeer, the former Head of the Department of Communication Science at the University of Zululand. Thank you for believing in me. May the good Lord bless you always. Secondly, to Dr. Rev. Emmanuel J. Moodley, who was the senior Pastor of Bethsaida Ministries International. He played a vital role in my life as a youth in my walk with the Lord and whilst I was in seminary. His passing away has left a major void in the body of Christ.

\section{References}

Abarim Publications (2021). Greek New Testament Concordance: Peter. [Available online at https://www.abarim-publications.com/Concordance/Names/c-Peter-1.html].

Abarim Publications (2021). Discover the meanings of thousands of Biblical names in Abarim Publications' Biblical Name Vault: Peter. [Available online at https://www.abarimpublications.com/Meaning/ Peter.html].

Anderson, R.L. (1991). Peters Letters: Progression for the Living and the Dead, Ensign, October 1991, 7.

Biblehub. (2021).Gatatians 2:28. [Available online at https://biblehub.com/galatians/2-8.htm]. Accessed on the 23 June 2021.

Bible.org. (2017). Jesus and the Religious Leaders. Retrieved from [Available online at https://bible.org/seriespage/48-jesus-and-religious-leaders]. [Accessed on 10 September 2021]. Cleary, S. (Ed.) (2) 
Bockmuehl, M. N. A. (2010). The Remembered Peter: In Ancient Reception and Modern Debate, Mohr Siebeck.

Demars, D. (2019). Was 1 Peter Written to Jews or Gentiles? Why the Answer Matters More Than You Might Think. Theology Finder. [Available online at https://derekdemars.com/2019/09/28/audience-of-1-peter-jews-or-gentiles/].

Du Toit, A.B. (1985). Guide to the New Testament. Vol. 5. Pretoria: NG Kerk Boekhandel (Edms) Bpk.

Du Toit, A.B. (1988). Guide to the New Testament. Vol 6. Pretoria, NG Kerk Boekhandel (Edms) Bpk.

Forrest, M. \& Oslon, M.A. (1978). Exploring Speech Communication,Minnesota: West Publishing Co.

Fritz, P. (2000). Techniques Of Christ's Communication Skills, Sermon Central [Available online at https://www.sermoncentral.com/sermons/techniques-of-christ-s-communicationskills-paul-fritz-sermon-on-20113].

Got Questions. (2021). Who was Peter in the Bible? [Available online at https://www.gotquestions.org/life-Peter.html]. Accessed on the 12 September 2021.

Horsfield, P. (1996). The Covenant Quarterly, Vol. LIV (3), August 1996), 26-37.

Ludlow, V. L. (1975). Major Jewish groups in the New Testament. [Available online at https://www.lds.org/ensign/1975/01/major-jewish-groups-in-the-new-testament?lang=eng]. [Accessed on 5 July 2021].

Mishra, S. (2017). Shannon and Weaver Model Of Communication. [Available online at https://www.businesstopia.net/communication/shannon-and-weaver-model-communication]. [Accessed on 2 January 2021].

Mersham, G. \& Skinner, C. (1999). New insights into Communication and Public Relation. Sandown: Heinemann Publishers (PTY) LTD.

Meyendorff, J. et al. (1963). The Primacy of Peter in the Orthodox Church, St. Vladimir's Seminary Press, Crestwood NY,

Nicolaides, A. (2021). Investigating the Holy Eucharist and the term 'people of God' according to the Eastern Orthodox Church, Pharos Journal of Theology, 102.

Nicolaides, A. (2020).Contemplating Christian ethics and spirituality for sound leadership in organisations, Pharos Journal of Theology, 101.

Nicolaides, A. (2019). Jesus the Christ: Truly the Theanthropos, Pharos Journal of Theology, 100.

Nicolaides, A. (2018). Mary Magdalene and Orthodoxy: Apostle, Heroine or Feminist? Pharos Journal of Theology, 99.

Nicolaides, A. (2010). 'The Laos tou Theou - an orthodox view of the "people of God"', HTS Teologiese Studies/Theological Studies, 66(1),

Reddy, M.M. (2018). The use of written communication by the early Christian leaders: for maintenance and the propagation of Christianity. Pharos Journal of Theology,99. [Available online at https://www.pharosjot.com/uploads/7/1/6/3/7163688/ article_5_vol_99_2018_reddy_-_unizul.pdf]. Accessed on the 12 January 2019.

Reddy, M.M. (2004). Communication in Christian groups from movements to organisations. Unpublished dissertation. Doctorate in Literature. University of Zululand. 
Reddy, M.M. (2002). Communication for maintenance and propagation: The forms of communication used by the cell church as an emerging organisation. Unpublished thesis. Master of Arts. University of Zululand.

Ridderbos, H.N. (1961). The Speeches of Peter in the Acts of the Apostles, The Tyndale New testament Lecture 1961.[Available online https://biblicalstudies.org.uk/pdf/tp/speeches_ridderbos.pdf]

Shuster, E. (2013). StudyChristianity.Com. [Available online at https://www.studychristianity.com/divine_communication.html]. Accessed on the 10 September 2021.

Siecienski, A. E. (2017). The Papacy and the Orthodox: Sources and History of a Debate, Oxford University Press

Stamps, D. C. (1990). The Full Life Study Bible - NIV. Florida: Life Publishers International. Taylor, C. \& Talyor, J. (2016). The Bible journey. [Available online at http://www.thebiblejourney.org/biblejourney $1 / 21$-the-romanojewish-world-of-thenewtestament/jewish-religious-leaders/]. Accessed on 6 August 2017].

Tenny, M. (1975). The Zondervan Pictorial Encyclopedia of the Bible, Michigan: Zondervan Publishing.

Tenny, M. C. (1978). New Testament Survey, Michigan: Eerdmans Publishing Company.

The New Book of Knowledge (Vol. 3). (1976). Canada: Grober Limited.

Tubbs, S. T. \& Moss, S. (1978). Interpersonal Communication. New York:

Vander Heeren, A. (1911). "Epistles of St. Peter" . In Herbermann, Charles (ed.). Catholic Encyclopedia. 11. New York: Robert Appleton Company.

White, L. (2021). 5 Things You May Not Know About Peter in the Bible. [Available online at https://www.beliefnet.com/faiths/christianity/5-things-you-may-not-know-about-peter-in-thebible.aspx]. Accessed on the 9 September 2021.

Wikipedia (2021). Saint Peter. [Available online at https://en.wikipedia.org/wiki/Saint_Peter]. Accessed on the 13 September 2021.

Wilson, R. M. (1979). Text and Interpretation: Studies in the New Testament, Cambridge University Press. 